\title{
Lesotho: Poverty Reduction Strategy Paper Status Report
}

Poverty Reduction Strategy Papers (PRSPs) are prepared by member countries in broad consultation with stakeholders and development partners, including the staffs of the World Bank and the IMF. Updated every three years with annual progress reports, they describe the country's macroeconomic, structural, and social policies in support of growth and poverty reduction, as well as associated external financing needs and major sources of financing. This country document for Lesotho, dated July, 2004, is being made available on the IMF website by agreement with the member country as a service to users of the IMF website.

To assist the IMF in evaluating the publication policy, reader comments are invited and may be sent by e-mail to publicationpolicy@imf.org.

Copies of this report are available to the public from

International Monetary Fund • Publication Services

$70019^{\text {th }}$ Street, N.W. • Washington, D.C. 20431

Telephone: (202) 623-7430 • Telefax: (202) 623-7201

E-mail: publications@imf.org•Internet: http://www.imf.org

\section{International Monetary Fund \\ Washington, D.C.}



STATUS OF THE PREPARATION OF PRSP

THE GOVERNMENT OF LESOTHO

JULY, 2004

REPORT PREPARED BY

THE MINISTRY OF FINANCE AND DEVELOPMENT PLANNING 


\section{INTRODUCTION}

This Report indicates the current status of the preparation of the Poverty Reduction Strategy Paper (PRSP) and briefly describes the major activities over the past year. As at June 2003, the preparation process had concluded wide-ranging community consultations (summarized in the draft report titled "Voice of the People"), input from sectoral working groups, input from thematic working groups on critical cross-cutting topics and their consolidation of these submissions into a draft operational document.

\section{A. Progress}

The main activities undertaken between July 2003 and June 2004 include:

- A costing exercise which analysed all of the proposed activities under each PRSP strategy and compiled indicative cost estimates;

- An updated assessment of the aggregate resource envelope based on the mediumterm fiscal strategy 2004/05-2006/07;

- A prioritisation exercise designed to identify the core activities to be included in the PRSP on the basis of their expected contribution to the national development objectives;

- Establishment of key performance indicators, baselines and targets for 2006/07 which will be used to monitor PRSP implementation;

- Drafting of the PRSP document, based on the operational document and reflecting the core priorities to be implemented under each strategic issues; and

- Editing and formatting of the final version of the PRSP document, incorporating comments from peer reviewers.

The Lesotho Poverty Reduction Strategy Paper is almost complete. It is ready for submission to the Committee of Principal Secretaries and to Cabinet for approval. Please see the timeline in Section D.

The PRSP is made up of the following documents:

- An executive summary

- The PRSP document, which is abridged and prioritized version of the operational document.

- An implementation matrix

- A cost matrix

- An indicators matrix with baselines and targets for 2006/07.

- An operational document that is more detailed from which all the other versions were derived. 


\section{B. Principles upon which Lesotho PRSP has been based}

The underlying principles in preparing Lesotho PRSP have been as follows:

a) Participation, inclusiveness and national ownership.

The PRSP Technical Working Group(TWG) that was given the responsibility to produce the PRSP was formed of representatives from Government, NGOs, Private Sector and development partners.

The PRSP document contains national challenges and priorities that emerged from wide stakeholder consultations, especially from community consultations. It also reflects objectives and strategies to be implemented over a three year period 2004/05-2006/07 under each of these national priority areas. It shows related indicative costs of the strategies and list the institutions responsible for their implementation. It also has key performance indicators and targets which will serve as a basis for monitoring the PRSP.

The PRSP emphasises the need to sustain participation and involvement of communities, private sectors and NGOs even during implementation for enhanced national ownership.

b) Adoption of a multisectoral, coordinated and integrated approach

Concerted efforts were undertaken to strengthen coordination in the PRSP process whilst ensuring a multisectoral approach to poverty reduction. A large component of the PRSP funding was also brought together under a common PRSP fund for better donor coordination.

\section{Harmonizing PRSP with other key initiatives}

The PRSP is a strategy for attaining the long term National Vision and the Millenium Development Goals. Alongside the PRSP, the Public Sector Improvement Reform Programme will be implemented to strengthen the capacity within the civil service for efficient service delivery.

\section{Way forward and timeline}

The timeline below reflects remaining activities and envisaged time for their execution: 


\begin{tabular}{|l|l|}
\hline PRSP endorsement by the Technical Working Group (TWG) & 11 August, 2004 \\
\hline $\begin{array}{l}\text { Deadline date for submission of comments by the Committee of } \\
\text { Principal Secretaries (PSs) }\end{array}$ & 27 August, 2004 \\
\hline Incorporation of comments from PSs & 8 September, 2004 \\
\hline $\begin{array}{l}\text { Deadline date for submission of comments by the Hon. Minister of } \\
\text { Finance and Development Planning }\end{array}$ & 22 September, 2004 \\
\hline $\begin{array}{l}\text { Incorporation of comments from the Hon. Min. of Finance and Dev. } \\
\text { Planning }\end{array}$ & 1 October, 2004 \\
\hline $\begin{array}{l}\text { Preparation of a Cabinet Memo and submission of the PRSP to } \\
\text { Cabinet for approval }\end{array}$ & 19 October, 2004 \\
\hline Incorporation of comments from cabinet & 29 October, 2004 \\
\hline Submission to World Bank/IMF & Early-Mid November, 2004 \\
\hline PRSP dissemination and implementation. & 2004/05-2006/07 \\
\hline
\end{tabular}

